\title{
Using Memory to Foster Community Among New Students
}

\author{
by John W. Tigue \\ Associate Academic Dean \\ Castleton State College
}

New students come to campus at the start of each semester. Prior to that, most attend an orientation program, joining other new students. They may meet with a peer leader and a faculty or staff advisor. Whether students are on campus to register for courses or to actually start them, they will meet many new people, including faculty, staff, and other students. As professionals who teach or work with new students a sense of community and belonging can be promoted by learning their names and helping them learn and recall the names of their peers.

\section{Developing Relationships and Community for New Students}

Higher education scholars such as Ernest Boyer, Alexander Astin, Laura Rendon, and Nancy Schlossberg have highlighted the importance of building community and valuing new students in their early days on campus. Boyer (1987), for example, wrote

the first weeks on campus are critically important. This is the time when friendships are formed and attitudes about collegiate life take shape.....New students have a strong urge to get acquainted and get along....The greater a student's social and academic integration, the more intense his or her commitment to the college (will be). (p. 43)

Astin (1993) emphasized that the peer group produces some of the strongest effects on student development and that a lack of student community has stronger direct effects on student satisfaction and retention than any other environmental measure. Next to the peer group, student-faculty interaction is the most significant aspect of the student's undergraduate development.

Schlossberg (1989) has alerted faculty and staff to the fact that feelings of marginality often occur as students take on new roles, especially when they are not sure 
of what to expect in the new environment. She defined marginality as a sense of not fitting in which can lead to self-consciousness, irritability, and depression. Schlossberg suggested that colleges and universities need to help students feel like they matter to others in the new academic and social setting.

Finally, Rendon (1994) has contributed the concept of validation to the understanding of new students. She described validation as "an enabling, confirming, and supportive process initiated by in- and out-of-class agents that foster academic and interpersonal development." (p. 46) Rendon suggested that validating agents can be instructors, classmates, and student affairs staff, among others. Validation is most powerful during the first few weeks of classes, according to Rendon.

\section{Using Mnemonic Techniques}

Learning students' names and helping them get to know each other is essential to the formation of community. A number of mnemonics make learning names easier. The use of "mnemonics," from the Greek word mneme, meaning memory, has its origins in Greek mythology, where the goddess of memory Mnemosyne shared her knowledge with her daughters, the nine muses, who put it into poems and songs so that they could be easily remembered by others (Campbell, Campbell, \& Dickinson, 1999).

Prior to learning new names, make sure objectives are clear. Also, involve as many senses as possible while using techniques that maintain interest and stimulate learning (Matte \& Green, 1995).

There are left- and right-brain memorization techniques. The left-brained learner proceeds logically and linearly, presenting information in the form of a list or outline. If it is a challenge to recall some names, use the points that Lowenstein and Todd (1999) suggested for taking a test, such as putting them on flash cards and carrying them around, so they can be reviewed easily. Names can also be put on Post-It notes that can be attached to a notebook or folder, glancing at them as needed.

The right-brained learner presents ideas as "spidergrams" or uses mapping, which incorporates holistic and kinesthetic processing. The following "Ball Toss" activity is an example of right-brain learning which incorporates movement. In this activity, the first person holding the ball says her/his name and tosses it to someone else, who thanks that person by name and says her/his own name. Students toss the ball from person to person until everyone receives it. The process continues until students are familiar with each others' names. Repeating the process, the order in which the students toss and receive the ball should remain the same. For example, "I'm Rachel (tosses the ball). Thank you, Rachel (catches the ball and speaks), I'm Jasmine (tosses the ball). Thank you, Jasmine, I'm Anthony..."

Another lively game is to have the students write on an index card something unique or exciting about themselves. The instructor collects, shuffles, and redistributes the cards to the students. After checking that no one has received her/his card, everyone stands up, wanders around the room, and finds the person whose card she/he holds. After matches are made, each person introduces his or her partner and describes that unique or exciting aspect about their partner to the rest of the class. 
Another card game for students is to have them write two statements about themselves that are true and one that is not. Students take turns introducing themselves and reading their statements to the class. Everyone guesses which two statements are true and which one is not. This is an enjoyable way for the group to become better acquainted and learn about their classmates or group members.

In very large lecture halls, realizing that not all student names will be learned, one strategy is to take attendance and then ask students to introduce themselves to the persons seated on both sides of them as well as in front of and back of them. At the very least, this activity helps students feel more connected to each other.

Calling on students by name when they ask or answer questions is helpful, and students then pay attention during class as they know that they are not anonymous. Especially in larger classes students can be assigned to small groups that meet periodically to discuss an assigned topic. Recording the names of the students in each group, circulating around the classroom, and sitting in on discussions, facilitates my learning their names. As an instructor or group leader, saying students' names as assignments are returned provides another opportunity to know them better.

Technology can assist in fostering community in a group or classroom. The act of typing the students' names increases familiarity with them, and class pictures can also be helpful. Pictures can be taken informally with an inexpensive digital camera.

\section{Conclusion}

The general memorization techniques and strategies described above certainly can apply to more than learning names. They can lead groups of new students in the initial stages of forming a community of learners, as advocated by Boyer, Astin, Schlossberg, and Rendon. By enhancing student-to-student and instructor-to-student relationships, these strategies help develop the bonds that will lead to greater adjustment, satisfaction, and success in the new environment.

\section{References}

Astin, A.W. (1993). What matters in college? four critical years revisited. San Francisco: Jossey-Bass.

Boyer, E. L. (1987). College: The undergraduate experience in America.

New York: Harper and Row.

Campbell, L., Campbell, B., \& Dickinson, D. (1999). Teaching and learning through multiple intelligences, (2nd ed.). Boston, MA: Allyn and Bacon.

Lowenstein, S., \& Todd, P. (1999). Frame by frame: A visual guide to college success. Upper Saddle River, New Jersey: Prentice-Hall, Inc.

Matte, N. L., \& Green-Henderson, S. H. (1995). Success your style! right-and leftbrain techniques for learning. Belmont, CA: Wadsworth.

Rendon, L. I. (1994). Validating culturally diverse students: Toward a new model of learning and student development. Innovative Higher Education, 19, 46. 
Schlossberg, N. K. (1989). Marginality and mattering: Key issues in building community. In D. C. Roberts (Ed.), Designing campus activities to foster a sense of community (New Directions for Student Services, No. 48, pp. 5-15). San Francisco: Jossey-Bass. 